\title{
Geographical explanations for the distribution of irrigation institutions Cases from Southeast Asia
}

\section{Introduction}

Rice, the staple food in most of monsoon Asia, is a versatile plant, with a large number of varieties adapted to specific geographical and soil conditions. Some varieties grow as a dryland crop, many others as a swamp land crop in inundated fields, while some varieties are adapted to high-rising floodwaters and are known as deepwater rice or floating rice. Water is a critical factor in rice cultivation. A regular flow of water is required to nurture the plant to the flowering and ripening stages. The water level needs to be sufficient to create soil conditions in which bacteria produce the nitrogen needed for plant growth, and the water needs to be flowing in order to remove toxic materials. Keeping the plants inundated has a further benefit for farmers, as it suppresses weed growth, a perennial problem in the tropics. If the fields are watered from a surface source, the water flow also brings nutrients. Although monsoon Asia is known for its torrential rains, rainfall is highly unequally distributed in the region; there are areas receiving only small amounts of rain, and experiencing six or more dry months. In these areas irrigation is crucial for rice cultivation. Whether irrigation is possible depends on the local geographical conditions.

In the course of time a wide variety of irrigation structures have been built in Southeast Asia, ranging from small-scale systems with simple weirs and off-take canals, to large-scale canal systems branching off into many smaller canals. Irrigation associations managing these systems equally show a variation. The distribution of different types of waterworks and accompanying institutions in Southeast Asia is not random. A closer inspection of irrigation structures in comparative perspective, shows that geographical variables, such as climatic and geomorphological or topographical conditions, play an important role in their distribution. 
Climatic conditions to a large extent determine the irrigation requirement. The amount of water needed to raise a crop depends on water availability, which is the result of local rainfall $(\mathrm{P})$ minus potential evapotranspiration (PET), that is, the water that potentially evaporates from the leaves of the plant and from the soil. Depending on the result of this equation, the irrigation requirement can be large or small.

Topography of the area influences the scale of irrigation systems and the possibility of creating storage reservoirs. In mountainous areas local communities can establish small-scale irrigation systems. In larger floodplains, larger management systems are needed. In river deltas, with an abundance of water during the wet season, and drought during the dry season, technologically more complex irrigation systems are required.

These two factors are broad constraints, setting the framework for specific irrigation structures. Although temperature is in principle a limiting factor as well, I will not take it into consideration, as I will limit my discussion to areas lying within the tropics (minimum temperature of the coldest month 18 degrees Celsius).

Wittfogel formulated his much criticized theory of hydraulic society on the basis of rainfall patterns. He distinguishes three basic levels of water management, each fitting a specific pattern of rainfall, namely, 1. rain-fed agriculture, where cultivation is dependent on natural precipitation, to be found in areas with abundant rainfall; 2 . hydro-agriculture, where cultivation is based on small-scale irrigation or local community-based water management, prevalent in areas with both a wet and a dry season; 3. hydraulic agriculture, characterized by the development of large-scale irrigation works, managed centrally by a bureaucracy, found in arid regions (Wittfogel 1931:188-291, 1957:18, 23).

Wittfogel's theory is based on a causal sequence, theorizing that the development of large-scale irrigation works led to the development of a large bureaucracy, which formed the foundation of a managerial state, with its particular Asian variety of 'oriental despotism'. Wittfogel argues that the construction and maintenance of large-scale waterworks required the deployment of a massive labour force, which could only be mobilized by an authoritarian and centralized state.

Critics of his theory have mustered empirical case studies to argue that state centralization is not a necessary concomitant of large-scale irrigation works. However, critics have often disregarded the fact that Wittfogel has consistently maintained that the classic 'hydraulic state' was to be found in arid regions (Hunt and Hunt 1976:390). The argument that in certain regions irrigation was not large-scale and the state was not centralized, is not a valid counter-argument, if that region had sufficient rainfall for hydro-agriculture.

A methodological problem of Wittfogel's hypothesis is, as several anthropologists have pointed out, that the issue of state centralization is ambiguous 
and difficult to operationalize (Kelly 1983; Hunt 1988). It is not clear whether the concept refers to centralization of irrigation management or of the state structure at large. At issue is the division of power in the government structure and the relationships between the levels of organization. Kelly (1983) has suggested using the distinction centralization versus decentralization for the internal structure of the irrigation organization and to use another dichotomy, namely, articulation versus autonomy to indicate whether the irrigation organization is integrated into the state structure or independent of it. Testing the hypothesis comparatively is hampered by the fact that there is not enough empirical material. As Hunt (this volume) has observed, there are more than one million irrigation systems in the world and we have empirical descriptions of no more than 200 of these.

One group of geographers and archaeologists (Rigg 1992) criticize Wittfogel's theory on the basis of a number of cases of irrigation systems in Southeast Asia. The most pertinent cases are from semi-arid regions on the continent. Geographer Stott (1992) shows that the Angkor temple complex in Cambodia, with its large system of canals, was not a hydraulic state, as the water from the canals was not used to irrigate the fields. Farmers acquired the water they needed for agriculture in another way. The religious use of water was totally separate from farmers' use of water. Similarly, archaeologist Stargardt shows for central Burma and southern Thailand that irrigation was organized by farmers. Completely reversing Wittfogel's argument, these authors attribute irrigation systems not to state interference, but to 'local irrigation associations', 'autonomous local groups' or 'irrigation communities' (Rigg 1992:4, 55, 69).

While their refutation of Wittfogel's theory of the centralized state is convincing, the alternative theory, attributing all irrigation systems to local farmers' communities, overlooks a serious problem. Under certain geographical conditions irrigation works require a large-scale outlay and this necessitates a high level of coordination and centralization both during the construction phase and in day-to-day management. This level is beyond the grasp of a local village community; it requires the cooperation of a large number of villages. Wade has criticized social scientists advocating small-scale irrigation structures in arid or semi-arid tropics. Wade (1995:2047) writes: 'In so arguing they overlook the qualitative difference in the context of farmers' behavior as between small-scale, communal systems in the semi-humid tropics, and large-scale, government-operated systems of the semi-arid tropics - a difference likely to make the application of organizational principles derived from the first context arduous in the second'.

Following Mitchell's suggestions (1973), we can split Wittfogel's hydraulic hypothesis into two separate hypotheses: 1. large-scale irrigation systems in arid or semi-arid regions require coordinating and directing activities at a higher level of organization than the village community; 2 . if there is cen- 
tralized direction of irrigation activities in an arid or semi-arid environment, there will be a corresponding increase of centralization in other areas of social life. This paper focuses on the first hypothesis.

American political scientist Elinor Ostrom $(1990,1993)$ has formulated a general approach to the problem of cooperation in irrigation systems, by using the term impure collective good or common pool resource (CPR), defined as a resource that is diminishable in use, while it is difficult to exclude potential appropriators. Common pool resources are prone to collective action problems, which occur when users prefer to free-ride on the resource, rather than cooperate in order to ensure its sustainable productivity. Ostrom is interested in the question under what conditions users are able to overcome this collective action problem and manage to institute norms and rules for the sustainable use of that particular resource. Ostrom $(1990,1993)$ has found that long-enduring irrigation systems are based on a number of design principles, such as clearly defined boundaries, collective-choice arrangements, and rules for monitoring users' behaviour. An important principle is that these systems are usually divided into many tiers of nested structures. Several levels can be distinguished, each with its own rules. The lowest layer consists of workteams in small parts of the system, monitoring each other's behaviour on the basis of operational rules, such as water-allocation arrangements. Those using a particular branch of the system form a higher level of organization. A third layer may involve all farmers served by one headwork. A fourth layer may involve all systems served by the same river.

The different levels of organization are attuned to the problems and activities on different geographical scales. Small-scale workteams can overcome free riding, because monitoring is facilitated by the fact that all activities are visible. The higher levels of organization deal with the problems of managing water distribution on a larger geographical scale. Ostrom (1993:1910) writes: 'By utilizing more than a single scale of organisation, many farmer-managed irrigation systems have sustained large-scale irrigation works for long periods of time relying primarily on their own resources without extensive help from external agencies'.

Ostrom shows in her studies that irrigation associations having these characteristics represent a form of communal property, that is, the organization manages a common pool resource (water) as a common property and maintains a complex and multi-tiered system of management practices and rules for this purpose. Anthropologist Lewis (1991:9) calls this type of irrigation associations 'corporate groups' defined as 'social groups that control the use of and inheritance of property, meet more or less regularly, and have representative leadership'. He points out that irrigation groups constitute a different kind of social organization than farming villages. A village is a residential group of farming families who own or lease land in private property. An irri- 
gation association has the collective ownership of resources, such as water rights, dams, canals, and, in some instances, land.

Lewis (1991:99) makes a broad distinction between two kinds of irrigator groups. The first is a loose form of cooperation between farmers from a local village community who have joined forces in local water management, without formal organization, remaining within and relying on the social relations in their community ('community based'). The second is an irrigation association that is independent of existing village institutions, and that has a corporate basis and communal ownership, distinct from the village community ('communally based').

This article attempts to show, on the basis of a number of case studies of traditional Southeast Asian irrigation systems, that under certain geographical conditions, the need for irrigation and topography of the area require the construction of large-scale irrigation works, and that the concomitant irrigation association is a form of communal property and represents a corporate group. Sometimes the higher-level organizations are articulated with the state structure. The case studies selected include both ancient and still functioning irrigation systems. Irrigation systems based on modern infrastructure and state bureaucratic management are not included.

\section{Climatic conditions}

The main biophysical determinants of agriculture are sunlight, precipitation and soil type. The main aspect is the distribution of rainfall or the availability of water throughout the year and the topography of the landscape determining the degree of runoff or retention. In temperate regions, seasonal variations are usually identified on the basis of temperature differences, but in the tropics rainfall is the important criterion, since mean temperatures vary so little from month to month. Thus in most tropical areas, the year is described in terms of wet and dry seasons.

Both wet and dry rice cultivation are largely concentrated in the monsoon region of Asia, where rice is a staple food. Wet rice cultivation requires the following conditions: 1 . a constant water supply during most of its growth period, either in the form of rain (10 $\mathrm{mm}$ per day) or in the form of irrigation water; 2. a warm humid atmosphere (temperature above 18 degrees Celsius); 3. flat land for rice fields; 4 . a dry period in the last phase of the plant's growth, particularly during ripening. This means that the best conditions for rice are found in areas with both wet and dry months.

The amount of irrigation needed for agriculture depends on the amount and distribution of local precipitation (P) on the one hand, and on potential evapotranspiration (PET) on the other. PET is the water that potentially evaporates from the leaves of a crop and from the land. PET is determined by 
climatic factors such as temperature, wind and air moisture. When total water supply (rainfall, soil moisture, irrigation) is sufficient to satisfy the amount of PET needed, crops can be grown (Wade 1995:2041).

We can get a rather clear picture of the need for irrigation in a region by comparing the rainfall distribution over the year (by month) (P) with potential evapotranspiration (PET) by month. The greater the shortage of rainfall in relation to PET during a certain period of the year, the greater the need for irrigation. Where rainfall is greater than or equal to PET, little irrigation is needed. When rainfall is significantly less than average PET, irrigation is necessary for harvests during deficient months. Wade (1995:2042) has proposed using the monthly figures of P minus PET as an indicator for water shortage and the need for irrigation.

Rain-fed rice cultivation is only possible in areas where P minus PET is positive for the duration of the growing season. If we take the requirement of $10 \mathrm{~mm}$ of rain per day as a starting point, an amount of water equivalent to precipitation of about $300 \mathrm{~mm}$ per month is required. PET usually is at a level of $100-130 \mathrm{~mm}$ per month, leaving about $170-200 \mathrm{~mm}$ for plant growth. If the P minus PET amount sinks much below that level, water has to be supplied from irrigation.

If we look at rainfall patterns in Southeast Asia, we can broadly distinguish three regions, high, moderate and low rainfall areas. High rainfall patterns with a short or no dry season (humid climate types) are located close to the equator and in mountain areas. Moderate rainfall patterns with a dry season (semi-humid climate types) lasting several months can be found in East Java and Bali, and the western and central parts of the Philippine islands. Low rainfall patterns with a very long dry season (semi-arid and arid climate types) can be found on the inland plains of continental Southeast Asia.

\section{Topography}

Southeast Asia presents a wide array of geomorphological forms, which have provided widely varying settings for irrigation facilities. Topographical factors play an important role in explaining the prevalence or absence of waterworks. For instance, the landscape can be flat, undulating with gently sloping hills, or sliced by steep ravines. As rainy mountain areas function as catchment areas, supplying the plains with a strong and often perennial flow of water, geomorphology deserves our attention.

The great river plains of the mountain-building zone of Southeast Asia all have similar topographical structures. The main rivers, Irrawaddy, Salween, Chao Phraya, Mekong and Red River, originate in the geologically active tertiary Himalaya mountain range and the geologically older extended ranges stretching to the south. 
In insular Southeast Asia a number of rivers have a similar structure, although they are much shorter than their continental counterparts. On the island of Luzon the Pampanga River, originating in the Sierra Madre mountain range, and on the island of Java the Brantas and Solo rivers have similar structures. These rivers have a basic dendritic structure: many small tributaries in the mountain areas converge to form a powerful main stream flowing through a plain, later dividing into various river arms flowing through a low-lying flat delta. Japanese geographers, geologists and agrarian historians from Kyoto University, carrying out research in Thailand in the 1960s and 1970s, have developed a model of the structure of Southeast Asian rivers, particularly of the continental ones (Ishii 1978). According to Japanese geologist Yoshikazu Takaya (1978) three topographically distinct sections of a river can be distinguished, a drainage region, a floodplain and a delta (see Figure 1).

Figure 1. Topographical divisions of Southeast Asian large rivers (after Takaya 1978:173)

Constricted river channel and floodplains

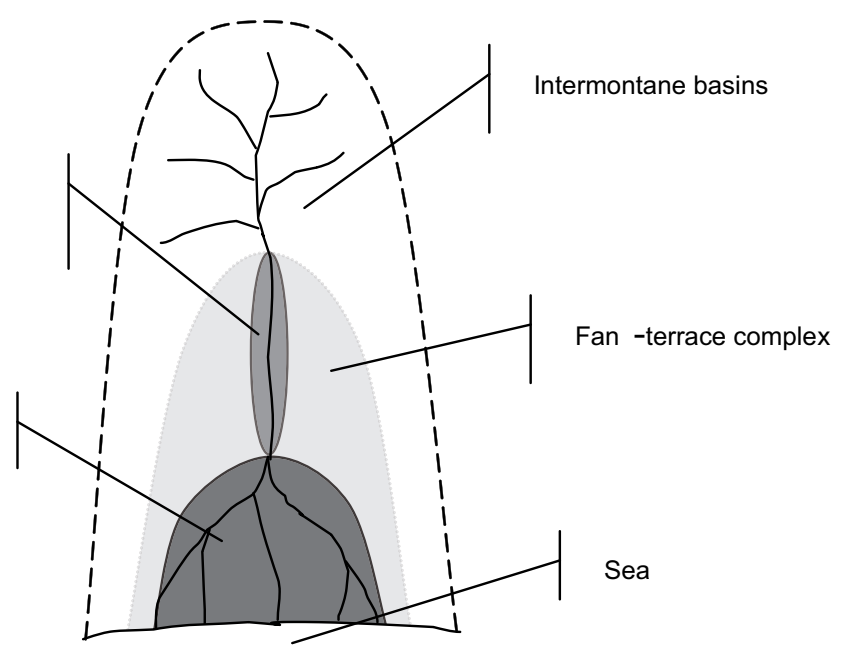

a. The drainage region is located in the mountains, where streams erode the slopes, forming relatively flat intermontane valleys and basins, making agriculture possible. These basins have relatively large water-catchment areas, so that there is ample water for rice cultivation. Both the topography and the small scale of the rivers allow for the construction of relatively simple dams and off-take structures, providing irrigation during the rainy season. The mountainous section of the river is suited for the construction of small dams, but often not for the construction of water reservoirs, as the 
small steep valleys would be able to hold only small amounts of water. It is here that one finds the oldest settlements and irrigation works.

b. Leaving the mountains, the river flows onto a wide plain, bounded by mountain ranges on both sides. The main stream flows through the centre of the plain and is bordered by floodplains from ten to twenty kilometres wide. Beyond the floodplains the land slopes gently upwards to the foothills of the mountain ranges along its flanks. Takaya (1978:172-3) calls this section of the river the constricted river channel, bordered by floodplains and surrounded on both sides by the upward-sloping plains of the fan-terrace complex. In the areas bordering this section of the river one finds the remnants of old civilizations.

c. In its lower reaches the river divides into various river arms, forming a low-lying delta area, where elevations alternate with extensive swamps. The lowest part of the delta closest to the sea is a tidal area, where during spring tides seawater penetrates upstream. During the wet season the amount of water flowing through the delta is huge. Because this water flow is unmanageable, the low-lying deltas of the large rivers of Southeast Asia were not brought under cultivation until late in the colonial period, in the late nineteenth and the first decades of the twentieth centuries. The modern (colonial) state, using modern technology, constructed the largescale irrigation and drainage works presently to be found in the delta section of rivers.

After the river leaves the mountains its large volume precludes small-scale irrigation structures. In the words of Japanese agricultural engineer Yoshihiro Kaida (1978:215): 'In the delta and the constricted river channel area individual or communal water control is impossible. The water is too powerful, and any local efforts to control it are likely to be wrecked by the slightest quirk of nature. Only large-scale government-sponsored works can be expected to have any effect at all. [...] In contrast, the conditions in the intermontane basins and the valleys bottom paddy fields at the apex of the fan-terrace complexes allow individual and communal approaches to water control.' Kaida (1978:209) is so convinced of the importance of these structures that he writes: 'The mode of irrigation and drainage of a paddy area is strictly dictated by its topography'.

\section{Water control infrastructure}

Waterworks are built for three different purposes: irrigation, drainage, and flood control. In the past, in rice-growing regions in monsoon Asia irrigation and drainage systems were constructed independently of flood-control dykes and canals (Bray 1986:68). Today, given the vastly increased financial and technical resources available, it is possible to construct water control systems integrating all three functions. 
We can distinguish different types of water control infrastructure:

1. Run-of-river systems, namely, a gravity system in which water is diverted from rivers and led through a transmission system of primary and secondary canals, incorporating weirs and gates as control structures. There are three subtypes:

a. Simple off-take constructions, whereby water is diverted from rivers by means of small dams and weirs, and led to the fields via 'contour canals' (Bray 1986:80) or bamboo pipes. These constructions are built and maintained by local farmers. Materials used are bamboo poles, rolling stones from the river bed, wood and leaves. These small-scale systems have the purpose of regulating the supply of water to rice fields during the wet season. As rivers run dry during the dry season, and water cannot be collected behind these makeshift dams, irrigation during the dry season is not possible.

b. Canal irrigation, whereby water is diverted from rivers via weirs or small dams into long canals that may run for dozens of kilometres, before reaching the fields. The construction and maintenance of the system of weirs and primary and secondary canals is a task that transcends the capabilities of a local village community. It involves several levels of organization, and various sets of rules for the allocation of water to users, for maintenance and for the resolution of internal conflict (Hunt and Hunt 1976).

c. During the twentieth century civil engineers constructed more complex irrigation constructions, made of cement or reinforced concrete, able to withstand heavy river discharges. The purpose is the same as that of smaller constructions: to regulate the flow of water during the rainy season, and thereby to control water delivery during the crucial period of crop growth, and to protect the crop from occasional periods of drought during the wet season.

2. Water storage systems can be found in both simple and complex forms. Older storage systems are the tanks found in semi-arid and arid regions of Thailand, upper Burma, India and Sri Lanka. Local farmers can construct these tanks, using locally available materials. Archaeologist Stargardt (1992:66) has shown that the large-scale tanks in Thailand and Burma were constructed by local farmers, using labour and materials in a very economic way, by choosing natural depressions in the landscape, which could be inundated effectively via a system of bunds, feeder canals, and sluices, and could be used to irrigate the fields via distributaries.

Technologically complex storage systems can be constructed by building a large dam in the river, creating a water reservoir for controlled releases, via a system of primary and secondary canals. These constructions are primarily designed for hydroelectric power generation and secondarily for other func- 
tions such as water supply, irrigation and flood control. Such systems were constructed on many rivers in the second half of the twentieth century, as large civil engineering projects involving huge costs.

High-rainfall regimes in upland and mountainous areas of insular Southeast Asia

In Southeast Asian areas where rainfall is abundant and (almost) year round, agriculture is mainly rain-fed and irrigation works are small-scale and local, used mainly to regulate the flow of water during the wet season, and where possible to provide water during the drier months. Local farmers, within the confines of the village community, manage the irrigation works. Such systems are found in the always-humid tropics, close to the equator, but also in mountain areas at higher latitudes. Annual rainfall is high, ranging from 2,000 to $4,000 \mathrm{~mm}$, and there is no dry month (with monthly rainfall below $100 \mathrm{~mm}$ ). Throughout the year precipitation is higher than potential evapotranspiration. This means that people can cultivate the land, while depending solely on the rains for water.

Figure 2. Monthly averages for rainfall $(\mathrm{P})$ and potential evapotranspiration (PET) for Kuala Lumpur, Malay Peninsula

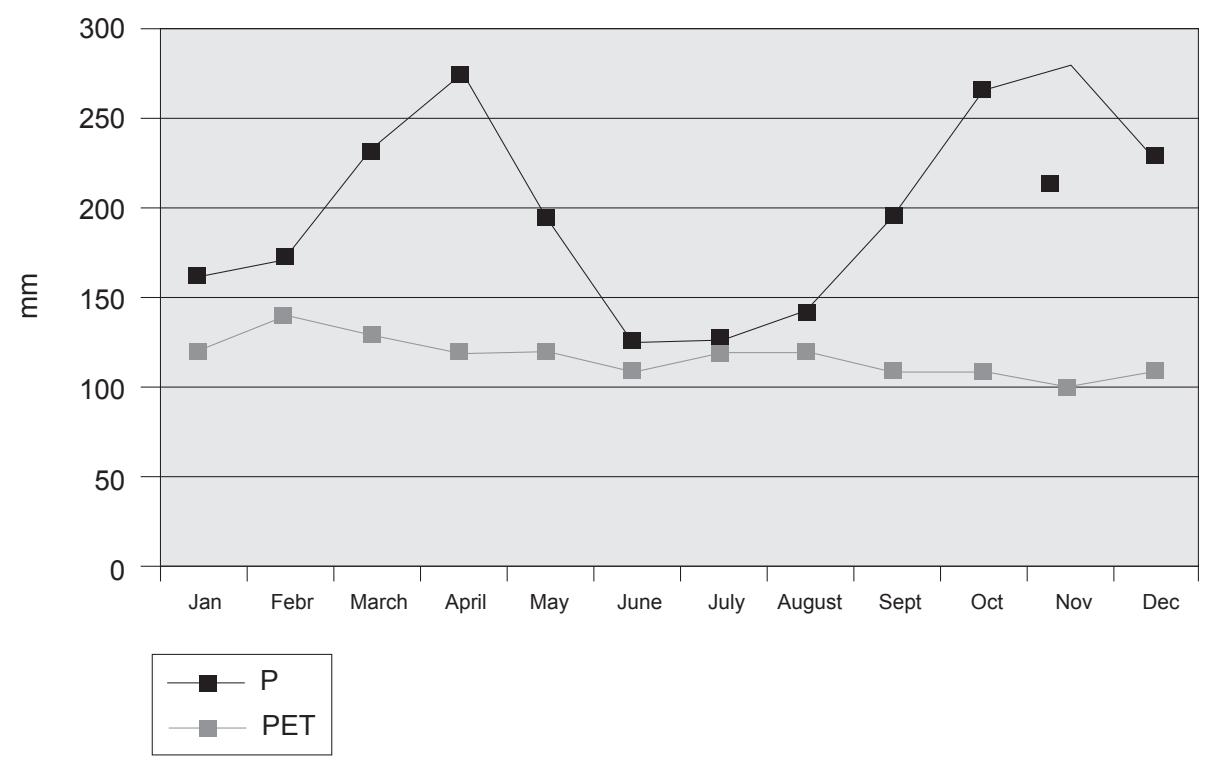

Source: rainfall data from World Climate Data: www.worldclimate.com; potential evapotranspiration data: Papadakis 1961:101 
In pre-colonial states on the Malay Peninsula wet rice cultivation was predominantly rain-fed, not on an irrigation basis (Halib 1985). It was only in the region of Negeri Sembilan and parts of Malacca that migrants from Minangkabau (Sumatra) constructed wet rice fields with simple irrigation structures. Water was obtained from brushwood dams in rivers and led via off-take canals to the fields.

In most parts of the island of Sumatra annual rainfall is high, ranging from 1,600 to $4,000 \mathrm{~mm}$. The highest rainfall is recorded along the west side of the Barisan mountain range, which is directly exposed to the humid air masses of the southwest monsoon. The oldest wet rice areas can be found, as historian Reid (1997) has shown, not in the river deltas or coastal plains, but in the intermontane basins of the highlands above 500 metres, in the Batak highlands, Minangkabau, Rejang and a few other small areas. The coastal plains were avoided because of uncontrollable flooding, unhealthy conditions, and dangers from maritime raiding expeditions.

Anthropologist Lando (1979) has studied Toba Batak social structure and irrigation associations. In some areas irrigation activities are carried out as part of village life; in other areas relatively independent units exist. In former times the associations were managed by descent groups, but at present voluntary groups from the villages are in charge. Although Lando describes a large irrigation system (with 206 members, covering 120 hectares), this association and other ones do not form an independent corporate unit, with communal property and an authority structure separate from the village structure.

The famous Ifugao rice terraces on the slopes of the Cordillera mountains in northern Luzon (Philippines) have an annual precipitation of over 3,000 $\mathrm{mm}$. This terraced landscape has been brilliantly described, photographed and mapped by anthropologist Harold Conklin (1980). Critics of Wittfogel's theory have used these impressive irrigation structures as an example of local farmers' creativity that did not require a complex bureaucratic structure. However, this is not a valid counter-argument, as rainfall is abundant and the terraces are kept inundated all year by local farmers' associations. The construction of these terraces did not require higher-level coordination. Conklin (1980:38) writes: 'There are no signs of a single prime mover or of a master plan for the development of Ifugao valleys [...]. Instead, all available cultural and environmental evidence indicates that the contemporary form of land use in Ifugao was developed in small increments by the forebears of the present inhabitants, over a period of many centuries, within this and adjacent regions of northern Luzon.'

In high rainfall areas most of the water needed for agriculture falls directly on the field. Waterworks are a supplementary facility adjusted to the topographical features of the landscape, meant to regulate the flow of water, and to drain the area. Irrigation is small-scale and the local community organizes the 
irrigators' groups. Larger associations of a communal and corporate nature are absent.

\section{Moderate and seasonal rainfall regimes in insular Southeast Asia}

In foothills and plains where annual rainfall is moderate and the dry season lasts for several months, rain-fed agriculture is possible during the wet season. Yet small-scale irrigation works are constructed to regulate the flow of water evenly during the wet season. If rivers are available that bring water from highrainfall mountain areas, and the topography allows for the construction of irrigation canals, chances are that people will have built waterworks of some kind. Large parts of the Indonesian and Philippine archipelagos as well as the coastal regions of continental Southeast Asia fall into this category. We find in these areas both small-scale irrigation works and larger canal systems with multi-layered irrigation associations. I will discuss examples from Central and East Java, Bali (Indonesia), and the Ilocos region in northern Luzon (Philippines).

Central and East Java and Bali typically have a bimodal rainfall pattern, while topography and geomorphology are favourable for irrigation works. Annual rainfall is moderate, in the range of 1,200-2,000 mm. The range of volcanoes stretching over the length of Java, rising from 1,500 to close to 4,000 meters above sea level, surrounded by hilly lands, create a large number of natural catchment areas varying in scale, most of which drain to the Java Sea. The rivers are relatively short, descending crosswise on the island's longitudinal axis. During the wet season (west monsoon) a tremendous amount of water flows downward, flooding large areas and causing significant damage, a phenomenon known and feared as banjir. During the dry season (east monsoon) eastern winds bring dry air, rainfall is reduced substantially, and rivers often fall completely dry.

For many centuries Javanese farmers have built simple small-scale irrigation systems. They constructed dams in rivers and led water via small canals to their fields. On mountain slopes people used hollow bamboo pipes to transport water over somewhat larger distances. The weakness of these simple structures was their makeshift character; during the wet season the dam was often swept away by strong currents.

Archaeologist Jan Wisseman Christie (1992 and this volume) has shown on the basis of the epigraphic record and archaeological findings, that large-scale irrigation works were absent in Central and East Java. State bureaucracies were not involved in irrigation management. To explain this, she points to topographical factors: the abundance of water coming down the slopes of the mountains, the relatively flat or undulating landscape of the foothills, and the gentle slope of these hills and of the small waterways. She writes: 'On Java the territory held by a community was relatively large, normally encompassing 
Figure 3. Monthly averages for rainfall $(\mathrm{P})$ and potential evapotranspiration (PET) for Pasuruan in East Java

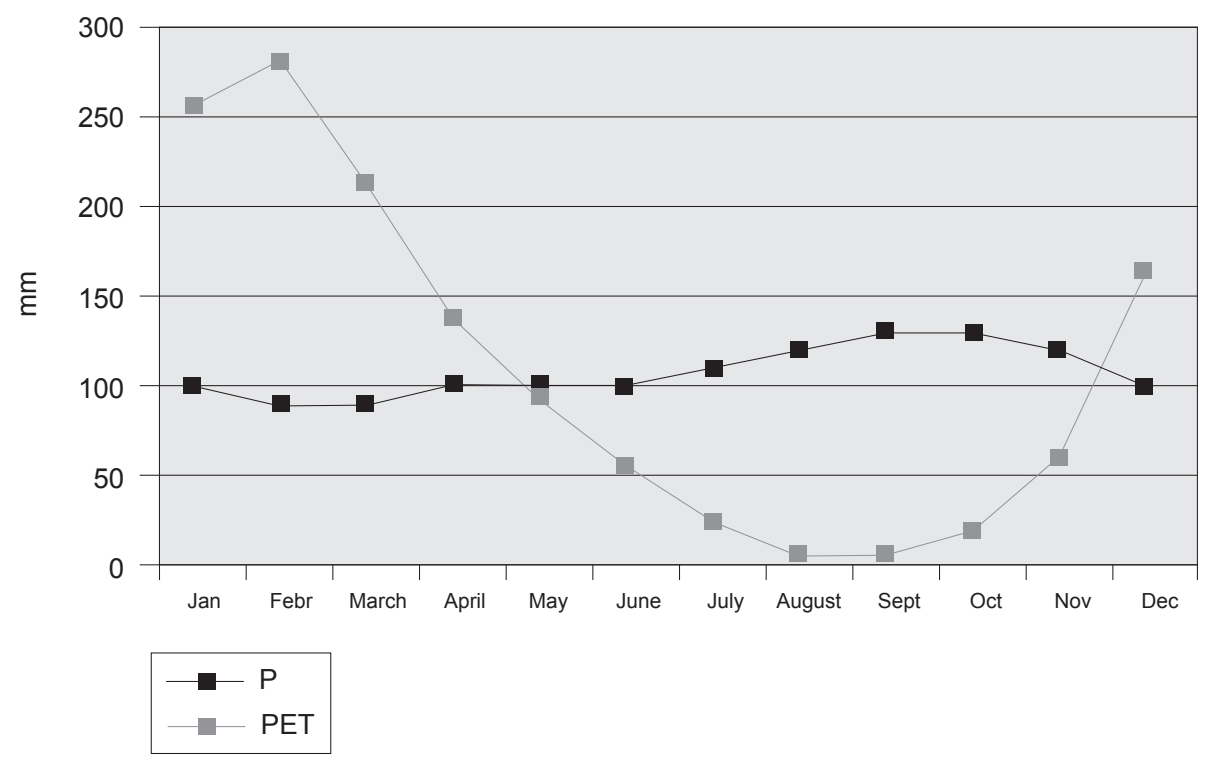

Source: rainfall data: Lekkerkerker 1938: 85; potential evapotranspiration data: Papadakis 1961:92.

much of the water used by its members, and the technical difficulties connected with the use of the water sources appear to have been minor, at least in the upland regions' (Christie 1992:16).

The island of Bali has a similar climate to East Java, with four to five months of dry season, but along the volcanic mountain slopes there is still some rain during the dry months (although less than $100 \mathrm{~mm}$ ). Aside from rainfall, agriculture can be irrigated from mountain lakes and underground outlets. The gradually downward slope from the mountain to the coast facilitates the draining off of water. The sloping terrain also facilitates the laying out of terraces. The rivers running down the mountain have cut deep gorges in the landscape, which hampers movement and communication along contour lines.

While Central and East Java had almost no large-scale irrigation systems in earlier times, Bali has had extensive irrigation systems for at least several centuries. Differences in topography explain this diverging development, as Christie $(1992: 12,16)$ has pointed out. Central and East Java's landscape, with gradual slopes, allowed farmers to manage water flows with smallscale waterworks. Along Bali's mountain slopes streams and rivers have cut deep ravines and gorges in the land, slicing the land into segments, running 
from the top to the plain. These ravines formed political boundaries between villages and between the old states. As the river down in the ravine lies far below the adjacent rice fields, farmers had to tap sources situated higher up the slopes, and bring the water to their fields via canals.

Balinese farmers formed cooperative groups, called subak, for the management and distribution of water. Observers during the colonial period often noted that Balinese were more sophisticated builders of waterworks than the Javanese. Balinese were able to construct long canals and tunnels through which water could be conducted, with very little loss over long distances (Liefrinck 1969:49). Presently, there are about 1,300 subak in Bali, covering approximately 110,000 hectares, while the size of one subak ranges from a few ha to almost 800 ha, with an average of about 100 ha (Horst 1996:36).

Balinese subak are decentralized and independent units, not controlled by a state bureaucracy. They are corporate organizations, based on the control of communal property, consisting of dams, canals, dikes, dividers, tunnels, aqueducts, reservoirs, and the water flowing through these structures. Geertz (1980) has pointed out that settlement units are distinct from irrigation units. Farmers in one hamlet can be members of different subak, while a subak has farmers from different hamlets among its members. The subak not only manages water flows, but also functions as a religious organization, performing rituals at the subak water temples.

Anthropologist Lansing $(1987,1991)$ has shown that the function of higher level coordination, above the subak, is carried out by a religious institution, namely, the network of water temples spanning entire watersheds, with the Temple of the Crater Lake standing at the summit of the system. The Temple, supervised by the high priest, is associated with the Goddess of the Lake and claims authority over the water in all of the irrigation systems of central Bali. The water temple system is separate from the state. Lansing argues that the water temple system has a practical function as well: scheduling the planting scheme, coordinating irrigation flows, and imposing a two-week fallow-period to control pests. The temple system does this on a watershed basis. Lansing has supported his theory with an ecological simulation model of hydrology, rice growth, and pest population dynamics. Anthropologist Falvo (2000), who doubts the validity of this modelling effort, has proposed an alternative explanation, arguing that the most important function in the past might have been keeping upstream subak from blocking the downstream flow of water, thus overcoming possible asymmetries among farmers using the same watershed.

The Ilocos region, on the northwest coast of Luzon (Philippines), is a small strip of land between the Cordillera central mountain area in the east and the China Sea in the west. The region has a row of mountain ranges running in an east-west direction, interspersed with small rivers and plains. A series of turbulent rivers descending from the Cordillera cross the coastal plains. The 
region thus comprises a number of small, flat river valleys separated from one another by intervening hills and ridges. Climatically the region falls under the semi-arid climate type, with a rainy season of three to four months and a dry season of six to seven months. The northern part of the Ilocos region is a major water-deficient area.

In the Ilocos region irrigation has traditionally been provided by rivervalley off-take systems, irrigating large parts of the valley. Irrigation is organized on a cooperative basis, whereby farmers form a zanjera, a water users association, consisting of a few to several hundred farmers who take their water from inlets connected with dams in the nearby river. The anthropologists Lewis (1971, 1991) and Siy (1982) have given detailed descriptions of these irrigation systems and associations. There are almost 1,000 zanjeras in Ilocos Norte, ranging in size from a few hectares to more than 900 hectares, covering a total of 18,000 to 20,000 hectares. The zanjeras are communal systems, based on membership and regulations requiring the members to contribute to the maintenance of the system. The main function of the irrigation societies is to provide a stable, reliable supply of water during the wet season (Lewis 1971:128).

The dams are constructed with communal labour, from bamboo and rocks, leading the water into complex systems of canals, small reservoirs, and drains (Lewis 1971:129). Traditionally the dams were made of simple materials. Lewis (1971:145) quotes the American engineer Christie, writing in the 1910s, who complained that these 'crudely constructed dams' were either completely destroyed or damaged each year. However, Lewis in retrospect rejects this judgment, and argues that the stone and bamboo dams were very practical under the prevailing conditions. The problem with the major rivers in the Ilocos region is that they have a very wide riverbed and consist of constantly shifting river channels and banks. Fixed concrete structures would not work under these circumstances, as they are vulnerable to turbulent floods during the wet season. When the simply constructed dams are washed away, it is relatively easy to build new ones, adjusted to the new river bed (Lewis 1991:73). A general feature of the traditional irrigation system in the Ilocos region was that it lacked water storage capacity (Wernstedt and Spencer 1967:335). As a consequence, on most rice fields only one crop per year was possible.

Lewis (1991:37-49) characterizes the zanjeras as well-defined corporate entities, possessing bounded organizational structures, having been legally incorporated with charters recognized by the state, with a clearly defined membership, and communal ownership of water, infrastructural facilities, and sometimes land. The zanjera is independent of the local residential units, hamlets and villages. 


\section{Low rainfall areas in mountainous areas in continental Southeast Asia}

The interior areas of mainland Southeast Asia, including South Vietnam, south and central Thailand and central or upper Burma, have a semi-arid climate. Annual rainfall is low, ranging from about 750 to $1,200 \mathrm{~mm}$, while distribution over the year is determined by the monsoons, with distinct wet and dry seasons, with a long dry period of five months or more. In some areas rainfall during the wet months hardly exceeds potential evapotranspiration. This means that in many areas climatic conditions are not suitable for rainfed rice agriculture. Rice cultivation is only possible if water is secured from other sources, such as rivers, via extensive irrigation structures. Remarkably, it is in these low-rainfall zones that pre-colonial civilizations, with elaborate urban centres and state structures, arose. In other areas seasonal floods are so overwhelming that drainage is necessary. In these areas specific forms of agriculture, adjusted to the flood conditions, developed.

The intermontane basins of northern Thailand are part of much larger region, encompassing similar areas in southern China, Laos, Vietnam and Burma, all having common characteristics: centuries long histories of wetrice cultivation, large-scale irrigation systems, stable social structures, and 'ancient' states. The Japanese researchers from Kyoto University who have studied northern Thailand (Ishii 1978) strongly emphasize the importance of climatic and topographical factors. Annual rainfall is low, and the dry season lasts for six months (see Figure 4).

Characteristic of this region is the presence of gravitational irrigation systems utilizing the natural flow of rivers and traditional diversionary weirs. In northern Thailand these systems are called fai-muang irrigation systems (fai are weirs and muang are canals) (Kaida 1978:211). These systems range from a few hectares to about 2,500 hectares. The local population makes the dams by driving bamboo stakes into the riverbed and filling the spaces between them with bamboo baskets containing rocks and stones (Ishii 1978:20).

In their studies of these irrigation systems, the Japanese researchers hark back to Wittfogel. Ishii (1978:18-9) argues that in regions having no available water sources, technological adaptation is needed to utilize the water coming from distant areas. Large-scale engineering works with trunk canals and reservoirs need to be constructed. Ishii (1978:18) writes: 'Such projects are beyond the capacity of the household or village, in terms both of the materials and manpower needed, and must be managed at a regional or national level'. Ishii (1978:19) refers to Wittfogel's theory of 'hydraulic agriculture', but realizes that the theory is 'inapplicable in its full sense' and softens it to 'quasihydraulic agriculture', in which the state participated in water control. He gives a number of historical examples where local rulers in northern Thailand ordered the construction of large-scale trunk canals, deriving their water from 
Figure 4. Monthly averages for rainfall $(\mathrm{P})$ and potential evapotranspiration (PET) for Chiengmai, northern Thailand

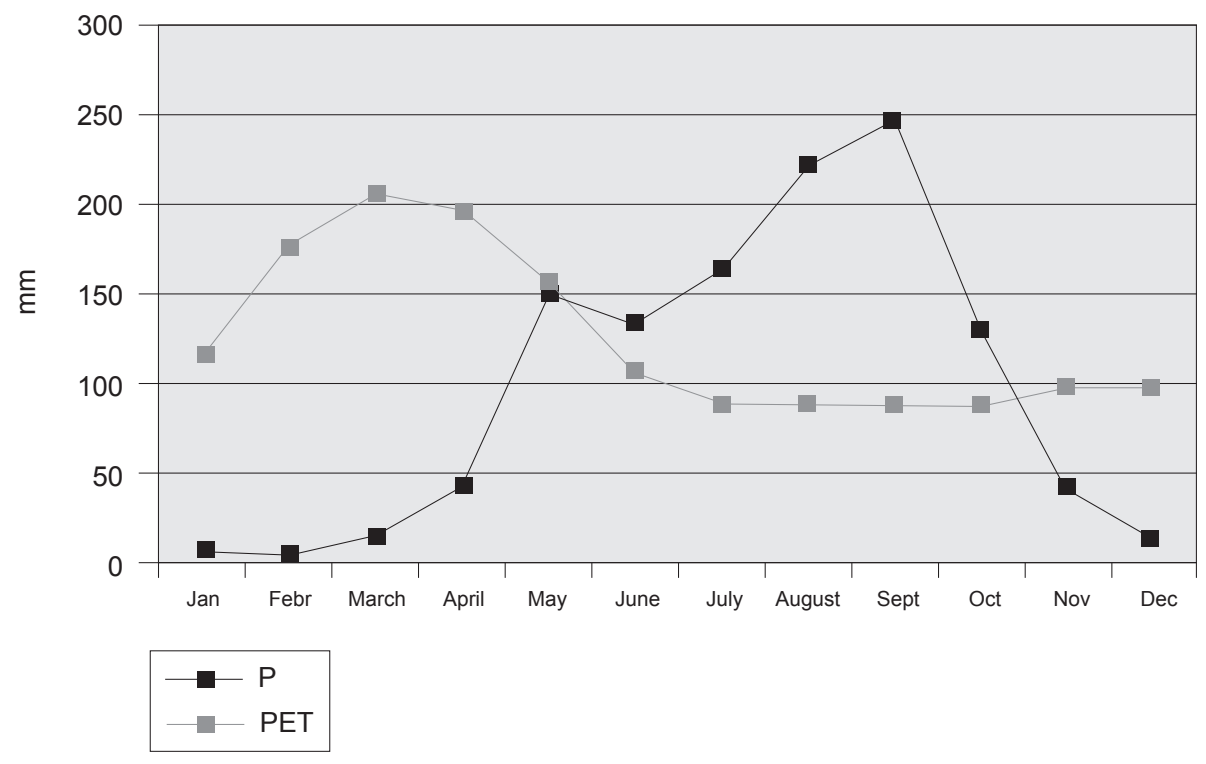

Source: rainfall data from World Climate: www.worldclimate.com; potential evapotranspiration: Papadakis 1961:114

the main rivers. These rulers mobilized corvée labour, to carry out projects, needing years to be completed. Ishii (1978:20-1) is sceptical about anthropological studies describing water management as practiced by the village community, because, as he writes, the basic structures were constructed under government supervision and financing. Ishii (1978:21) makes a rough calculation about one 34-kilometre-long canal (constructed in 1281) which supplied water to about 10,000 hectares of paddy fields, which at that time produced an amount of rice sufficient to feed a population of about 100,000 people, 'a figure clearly in excess of a village population'.

American anthropologist Potter (1976) has done fieldwork in a village in the Chiengmai valley in northern Thailand. He describes the large-scale irrigation works in the region as a segmented system, managed by a multi-tiered irrigation organization, coordinating the supply of water to a large number of villages (Potter 1976:81-102). He describes in more detail one irrigation system taking off from Ping River, where the members have constructed a weir, leading the water into a main canal, which splits into two large segments, which in turn split into seven major canals, each serving one or more villages, splitting again into minor canals, serving hamlets, splitting again into myriads of minor canals. The total number of farmers served by this system is about 1,600. 
The irrigation association managing this system closely parallels the physical outlay, with officials assigned to each of the levels of organization, with a headman at the top. Although Potter does not use the term 'corporate group', his description of the association clearly suggests its corporate character, with its well-defined membership, rules prescribing the rights and duties of the members, communal ownership of the weir and the canals, authority of association officials over the members, and their supervision of all labour and their right to inspect the work done. The farmer members of the association are obliged to clean the irrigation canals at all levels, and to rebuild the weir every year. The higher level of leaders manages conflicts between parts of the system. Higher state authorities manage conflicts between systems off-taking from different headworks at the river. With his analysis Potter (1976:102) supports, as he says, 'essential parts of Wittfogel's and Steward's theory'. The way he depicts the relationship between the irrigation organization and the state can best be characterized by using Kelly's term 'articulation' (which Potter does not use), denoting that the irrigation association is a bottom-up farmers' activity, while a state-level authority is needed to organize and mediate when conflicts between irrigation systems arise. In former times the Chiengmai kingdom performed this function; since its downfall, the Thai government has had to furnish this 'necessary central control'.

\section{The constricted river channel and the floodplains}

The floodplains around the constricted river channel in the middle reaches of the river and in the lower delta present a different ecological context. During the rainy season tremendous amounts of water come down the river from the mountainous catchment areas, and during the dry season the region is hit by drought. Throughout the centuries the farming population has found it impossible to control the floodplain through water management. Yet one finds in these regions the centres of old civilizations.

The farming population in these regions has adapted to the ecological conditions by developing particular forms of floodplain agriculture. One form of adaptation is growing floating rice varieties in areas covered with floodwater. Floating rice is a rice variety, which can grow rapidly, up to twenty centimetres a day, if floodwaters rise quickly and can thus avoid submersion even if water levels rise to three to four metres. When the water level falls, the long stem of the rice plant 'kneels down' and where the stem hits the soil, it starts rooting. Harvesting normally takes place a short time after the recession of the floodwaters.

Another form of adaptation is practicing 'receding flood' agriculture (Van Liere 1980), where farmers use the floodwater from rivers to inundate the fields. These rivers start to rise with the wet monsoon in July and begin to 
recede in November. Throughout the centuries farmers have constructed flood-retarding dikes and bunds, as well as small reservoirs using natural depressions in the landscape, to catch the water. Farmers can transplant or broadcast rice immediately after the retreat of the flood, and harvest in February or March. Archaeologist and irrigation engineer Van Liere (1980) has described 'receding flood' agriculture for the area around Angkor, bordering the Great Lake in Cambodia, where farmers used the annual incursion and retreat of water from the Siem Reap River (a tributary of the Mekong River) and the lake, and for the floodplains of the Mun and Chin rivers (tributaries of the Mekong River) in northeast Thailand.

Van Liere (1980) has shown that the theocratic superstructure of Angkor, the system of a divine king, a large priesthood, sacred temples and monasteries, temple ponds and canals, moats around the city, in short the whole system of theocratic hydraulics, was totally disconnected from agriculture. The canals supplying water to the temples did not bring water to the fields. Van Liere argues that theocratic hydraulics was technologically limited, as it was not possible to build permanent weirs in monsoon rivers or clay dams around reservoirs. The dams were small earthworks on minor streams in the foothills nearby.

Generalizing from Van Liere's analysis, geographer Stott (1992) has argued that Wittfogel's hydraulic paradigm must be replaced by a new paradigm of local management of water. He considers flood-retreat agriculture as a brilliant farmer-level response to a distinctive set of environmental conditions, a form of hydro-agriculture. Angkor was not, as several historians have said, a 'hydraulic state'. Stott includes in this view the muang fai systems of northern Thailand and the irrigation systems of the Burmese dry zone, and a number of other irrigation works. While Stott's argument is correct in rejecting Wittfogel's theory for Angkor, and in highlighting Van Liere's discovery of a specific form of hydro-agriculture, his generalization is unwarranted, because he underestimates the importance of topography and the need for large-scale waterworks in certain types of landscape and the organizational problems farmers encounter when they try to build such works. Besides, it should be remarked that Wittfogel has presented a theory or hypothesis, not a paradigm. Stott's suggestion that the Angkor state was based on a farming population practising flood-retreat agriculture, and that this form of agriculture 'was probably producing a rice surplus' before the state was established, is another hypothesis, not a 'new paradigm'. A hypothesis is a statement that can be empirically tested; a paradigm is a conceptual and methodological approach.

Upper Burma, also known as the Dry Zone, has a mean annual rainfall of 500 to 800 millimetres, while some areas receive not more than $200 \mathrm{~mm}$ (see Figure 5). This area was therefore not suited for rain-fed agriculture. Topographically the area falls within what Takaya has called the 'constricted river channel' of the Irrawaddy River and its tributaries. This means that the peren- 
nial river brings water from an enormous catchment area including the mountain regions in the north and on the sides of the plain. During the rainy season water rises rapidly in the area and large parts of the riverbanks are flooded.

Figure 5. Monthly averages for rainfall $(\mathrm{P})$ and potential evapotranspiration (PET) for Mandalay, Burma

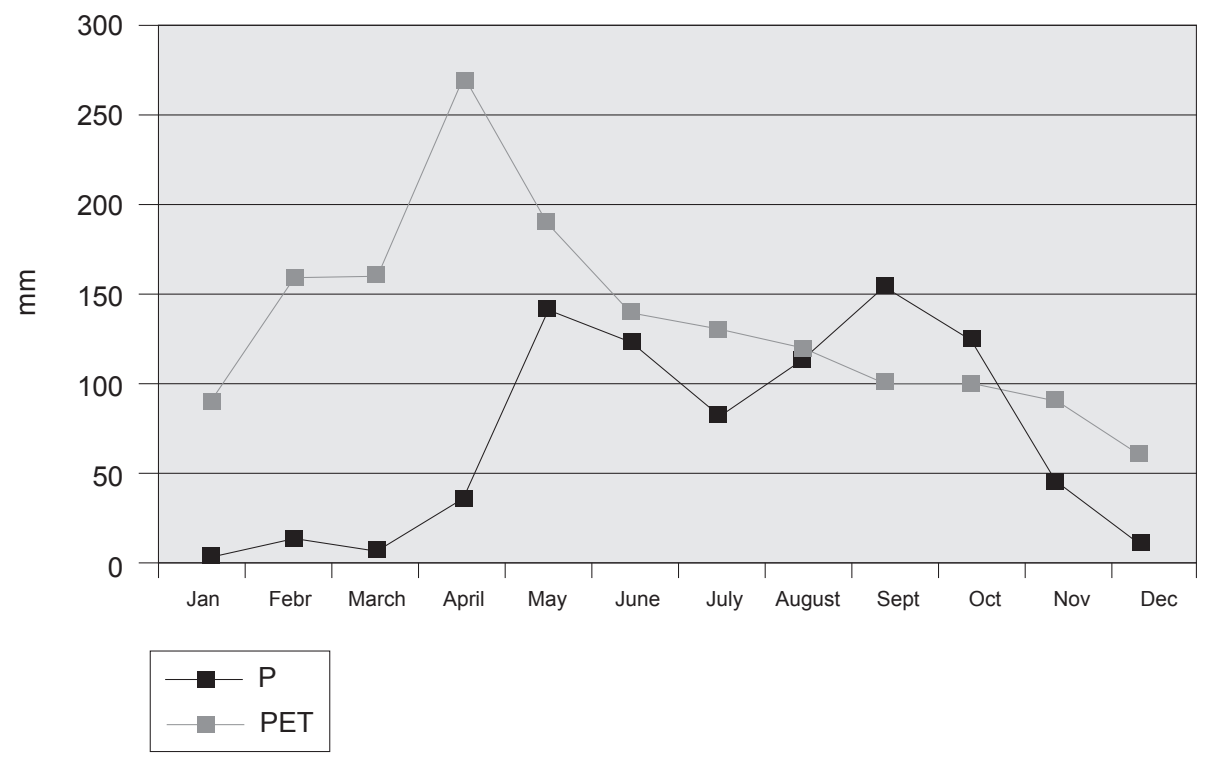

Source: rainfall data from World Climate: www.worldclimate.com; potential evapotranspiration: Papadakis 1961:73

Remarkably, this Dry Zone was the heartland of pre-colonial states for almost two millennia (with the exception of a brief period in the sixteenth century, when a dynasty moved the seat of government to Lower Burma). The Dry Zone was strategically located, for it allowed the rulers to control Lower Burma as well. In the second half of the nineteenth century the British colonial government established itself in Rangoon in the delta region. The low-lying delta was opened up and brought under cultivation, and turned into a major rice-producing area. Large numbers of migrants from Upper Burma moved to the south, undermining the population basis of the Upper Burmese states.

The highly developed ancient states of Upper Burma had been based on wet-rice agriculture. The rivers running through the region originate in mountain areas with heavier rainfall, and bring water to the plains throughout the year, and could be tapped for irrigation. Remarkably, the old centres were not located directly near the Irrawaddy River, but along its tributaries. The reason is probably that the water flow in these relatively smaller rivers, 
although uncontrollable as well during the wet season, was more predictable than the flow in the Irrawaddy River. After the beginning of the wet monsoon the rivers brought huge amounts of water from the mountains and flooded parts of the floodplain.

In the Dry Zone, wet-rice cultivation was possible in different ways. One was the system of flood-receding agriculture, described for Thailand by Van Liere (1980). This system was practised on riverbanks flooded during the rainy season. A special variety of rice, 'a cold and dry weather rice' (Aung-Thwin 1990:9), was sown in November or December on lands from which the water was subsiding, and harvested in March. On irrigated land other rice varieties were planted in June, and harvested in November. Fast-ripening varieties could be planted in March and harvested in June.

During the two millennia rule of the early states, large-scale irrigation systems were constructed in the region. From 1890 onward the British modernized and changed Upper Burma's irrigation systems. Historian Aung-Thwin (1990) has given a detailed description of the old systems, based on historical documents. The origin of some of the systems can be traced back to the first century $\mathrm{BC}$. Throughout the centuries new systems were built and existing systems were expanded. Aung-Thwin (1990) shows, on the basis of historical records, that kings often took the initiative in constructing canals, reservoirs, tanks, and large dams. Farmers probably constructed the secondary and tertiary structures.

The irrigation systems were built with traditional technology using local materials. British irrigation officers reported that the weirs were constructed with skill, but that they constantly required repair (Aung-Thwin 1990:16-7). The purpose of the weir was not to raise the level of the water, but to direct the flow into diversionary canals. These canals then split into smaller canals, which eventually delivered the water to the fields. Each irrigation system was named after the major weir at the headworks. The irrigation systems served areas varying from a few hundred to a few thousand hectares.

Stargardt (1992) discusses the role of irrigation associations in the old Upper Burmese states, on the basis of archaeological findings and the late nineteenthcentury records of British engineers inspecting the systems. She characterizes what she calls 'local associations' as cohesive structures, with very detailed regulations and procedures relating both to irrigation and the irrigation communities. Stargardt (1992:63) writes: 'The local irrigation associations that were at times integrated into larger political units [...] retained a degree of autonomy at all times, and were thus able to function during the recurring periods of civil war, or the collapse of central authority through some other cause.' The term 'local' probably underestimates the scale of operations of these associations. It would be interesting to find out whether these irrigation associations functioned as corporate organizations, with communal ownership of water flows and irrigation infrastructure, including the large canals. 


\section{Conclusion}

This article attempts to show that geographical factors, particularly rainfall distribution and the topography of the landscape, can to a large extent explain the distribution of the various forms of irrigation organization in Southeast Asia. With regard to rainfall three broad patterns can be distinguished, high, moderate, and low rainfall regimes. With regard to topography, a crucial distinction is that between the different sections of the large rivers, the intermontane basins upstream, the mid-section of the constricted river channel and adjacent floodplains, and the huge floodplains of the delta downstream. Another topographical distinction is between the gradually sloping mountains in Java and the heavily sliced landscape of Bali. Broad correlations are made between the geographical factors mentioned and the different types of irrigation organizations.

In summarizing the argument, I distinguish between insular Southeast Asia, including the Malay Peninsula, and continental Southeast Asia with adjacent South Asia.

Insular Southeast Asia has high to moderate rainfall regimes, while certain regions experience a short dry season. Topographically the landscape has relatively short rivers. In the upland and intermontane basins of the Malay Peninsula and the west coast of Sumatra, irrigation systems are absent or little developed, and irrigation associations are village based. Rainfall pattern and landscape make large-scale waterworks superfluous.

In the moderate rainfall areas, we find that early states in Central and East Java did not have extensive large-scale waterworks. Bali, on the other hand, has a centuries-old tradition of complicated irrigation works and irrigation associations, subak, with a corporate character. This difference between Java and Bali can be explained by differences in topographical conditions. The zanjeras in Ilocos Norte (Philippines) are situated in a moderate rainfall area, along the banks of rivers in the foothills between the mountains and the very small floodplains along the coast. As Lewis (1991) has pointed out, these irrigation associations have a very strong corporate organization, with communal ownership of water rights and facilities. Geographical factors explain these features. Rainfall is seasonal and irregular, and farmers have to make good use of the water flow in the rivers coming down the mountains. The topography allows the construction of long canals.

Continental Southeast Asia has rainfall regimes varying from moderate to low. Topographically, extremely long rivers, flowing north-south characterize the region. The large rivers originate or have tributaries originating in the Himalayas. Here we have to distinguish between the three river sections.

In the intermontane basins upstream in northern Thailand one finds the 
muang fai irrigation systems, managed by irrigation associations with a corporate character. The low rainfall makes it necessary to use water from the river, the moderate flow of the rivers makes it possible to construct weirs, and the landscape makes it possible to construct long canals. Interestingly, the traditional technology of weir and canal construction in northern Thailand is very similar to that of Ilocos Norte in the Philippines.

The middle section of the large continental rivers, with a constricted river channel and floodplains, has a very different character. These areas receive little rainwater, even during the wet season, but huge amounts of water come down from the mountains. Here one finds different systems side by side. Near the river and the lakes, where the land is flooded during the rainy season, recedingflood agriculture is practised at the end of that season. An alternative system is using floating rice, which is sown just before the floods, and harvested when the waters are still high. Another way of getting water is by constructing largescale canals, taking off water from the rivers and leading it to the fields.

In the third river section, the low-lying delta near the coast, rainfall is much higher and large amounts of water come down the river during the wet season. These areas have been uninhabited for centuries and were opened up starting in the nineteenth century. It was the late colonial state or (in the case of Thailand) the modern state that undertook the construction of large-scale drainage canals, irrigation works and, where necessary, large dams on rivers.

A number of studies during recent decades have shown that Wittfogel's hypothesis of a hydraulic bureaucracy of ancient states managing large-scale irrigation systems cannot be empirically corroborated. In many cases farmers, on the basis of their knowledge of geographical conditions, have managed irrigation associations, under community or communal management. However, this does not mean that community management has historically been the rule. Some authors have too easily concluded that irrigation was everywhere small-scale and carried out by local farming communities. This characterization fails to take into account the dimensions of water problems and the scale of operations necessary for water control. Especially in the larger floodplains, larger management systems were needed. Corporate irrigation associations were found locally with a legal character (recognized by the state), as the lowest units in a multi-tiered system involving regional and state institutions as well.

\section{Acknowledgements}

Constructive comments on earlier drafts of this paper by Peter Boomgaard, David Henley and Taco Bottema, literature suggestions by Wout Ultee and technical assistance by Andrew Wolters, are gratefully acknowledged. All responsibility for the argument rests with the author. 


\section{Bibliography}

Aung-Thwin, Michael

$1990 \quad$ Irrigation in the heartland of Burma; Foundations of the pre-colonial Burmese state. DeKalb, Ill.: Centre for Southeast Asian Studies, Northern Illinois University. [Occasional Paper 15.]

Bray, Francesca

1986 The rice economies; Technology and development in Asian societies. Berkeley: University of California Press.

Christie, Jan Wisseman

1992

'Water from the ancestors; Irrigation in early Java and Bali', in: Rigg, Jonathan (ed.), The gift of water; Water management, cosmology and the state in South East Asia, pp. 7-25. London: School of Oriental and African Studies, University of London.

Conklin, Harold C.

$1980 \quad$ Ethnographic atlas of Ifugao; A study of environment, culture, and society in northern Luzon. New Haven/London: Yale University Press.

Falvo, Daniel J.

2000 'On modeling Balinese water temple networks as complex adaptive systems', Human Ecology 28-4:641-9.

Geertz, Clifford

1980 'Organization of the Balinese subak', in: E. Walter Coward, Jr. (ed.), Irrigation and agricultural development in Asia; Perspectives from the social sciences, pp. 70-90. Ithaca/London: Cornell University Press.

Halib, Mohammed bin

1985 The state, rice, and irrigation; Historical development and contemporary cases of small-scale irrigation systems in peninsular Malaysia. PhD thesis Cornell University.

Horst, Lucas

1996

'Intervention in irrigation water division in Bali, Indonesia', in: Geert Diemer and Frans P. Huibers (eds), Crops, people and irrigation; Water allocation practices of farmers and engineers, pp. 34-52. London: Intermediate Technology Publications.

Hunt, Robert C.

$1988 \quad$ 'Size and structure of authority in canal irrigation systems', Journal of Anthropological Research 44:335-55.

Hunt, Robert C. and Eva Hunt

1976 'Canal irrigation and local social organisation', Current Anthropology 17-3:389-410.

Ishii, Yoneo (ed.)

1978 Thailand; A rice-growing society. Honolulu: University of Hawaii Press. [Monographs of the Center for Southeast Asian Studies, Kyoto University.]

Kaida, Yoshihiro

1978

'Irrigation and drainage present and future', in: Yoneo Ishii (ed.), Thailand; A rice-growing society, pp. 205-45. Honolulu: University of Hawaii Press. [Monographs of the Center for Southeast Asian Studies, Kyoto University.] 
Kelly, William

1983 'Concepts in the anthropological study of irrigation', American Anthropologist 85:880-6.

Kyuma, Kazutake

1978 'Nature and rice-growing', in: Yoneo Ishii (ed.), Thailand; A rice-growing society, pp. 164-70. Honolulu: University of Hawaii Press. [Monographs of the Center for Southeast Asian Studies, Kyoto University.]

Lando, Richard

1979 The gift of land; Irrigation and social structure in a Toba Batak village. PhD thesis University of California, Riverside.

Lansing, J. Stephen

1987 'Balinese "water temples" and the management of irrigation', American Anthropologist 89-2:326-41.

$1991 \quad$ Priests and programmers; Technologies of power in the engineered landscape of Bali. Princeton, NJ: Princeton University Press.

Lekkerkerker, Cornelis

1938 Land en volk van Java, deel 1, Inleiding en algemeene beschrijving met losse bijlagen over de administratieve indeeling en de sterkte van

Lewis, Henry T. bevolkingsgroepen. Groningen: Wolters.

1971 Ilocano rice farmers; A comparative study of two Philippine barrios. Honolulu: University of Hawaii Press.

1991

Ilocano irrigation; The corporate resolution. Honolulu: University of Hawaii Press.

Liefrinck, F.A. 1969

'Rice cultivation in northern Bali,' in: Bali; Further studies in life, thought and ritual, pp. 1-73. The Hague: Van Hoeve. [First published in Dutch in Indische Gids 1886.]

Mitchell, William P.

1973 'The hydraulic hypothesis; A reappraisal', Current Anthropology 14:5324.

Ostrom, Elinor

1990 Governing the commons; The evolution of institutions for collective action. Cambridge: Cambridge University Press.

1993 'Design principles in long-enduring irrigation institutions', Water Resources Research 29-7:1907-12.

Papadakis, J.

1961

Climatic tables of the world: evapotranspiration month by month and annual; humidity index. Buenos Aires.

Potter, Jack M. 1976

Thai peasant social structure. Chicago/London: University of Chicago Press.

Reid, Anthony 1997

'Inside out; The colonial displacement of Sumatra's population', in: Peter Boomgaard, Freek Colombijn and David Henley (eds), Paper landscapes; Explorations in the environmental history of Indonesia, pp. 61-120. Leiden: KITLV Press. [Verhandelingen 178.] 
Rigg, Jonathan

1992a

'The gift of water', in: Jonathan Rigg, The gift of water; Water management, cosmology and the state in South East Asia, pp. 1-6. London: School of Oriental and African Studies, University of London.

$1992 b$

(ed.) The gift of water; Water management, cosmology and the state in South East Asia. London: School of Oriental and African Studies, University of London.

Siy Jr., Robert Y.

1982 Community resource management; Lessons from the Zanjera. Quezon City: University of the Philippines Press.

Stargardt, Janice

1992

'Water for courts or countryside; Archaeological evidence from Burma and Thailand reviewed', in: Jonathan Rigg (ed.), The gift of water; Water management, cosmology and the state in South East Asia, pp. 59-72. London: School of Oriental and African Studies, University of London.

Stott, Philip

1992

'Angkor: Shifting the hydraulic paradigm', in: Jonathan Rigg (ed.), The gift of water; Water management, cosmology and the state in South East Asia, pp. 47-58. London: School of Oriental and African Studies, University of London.

Takaya, Yoshikazu

1978 'Landform and rice-growing', in: Yoneo Ishii (ed.), Thailand; A ricegrowing society, pp. 171-202. Honolulu: University of Hawaii Press. [Monographs of the Center for Southeast Asian Studies, Kyoto University.]

Van Liere, W.J.

1980 'Traditional water management in the lower Mekong basin', World Archaeology 11-3:265-80.

Wade, Robert

1995 'The ecological basis of irrigation institutions; East and South Asia', World Development 23-12:2041-9.

Wernstedt, Frederick L. and J.E. Spencer

1967 The Philippine island world; A physical, cultural, and regional geography. Berkeley: University of California Press.

Wittfogel, Karl A.

$1931 \quad$ Wirtschaft und Gesellschaft Chinas; Versuch der wissenschaftlichen Analyse einer grossen asiatischen Agrargesellschaft. Erster Teil, Produktivkräfte, Produktions- und Zirkulationsprozess. Leipzig: Hirschfeld.

Oriental despotism; A comparative study of total power. New Haven: Yale University Press. 